Sains Malaysiana 49(8)(2020): 1995-2003

http://dx.doi.org/10.17576/jsm-2020-4908-22

\title{
Effects of Aided Smoking Cessation Counselling with Exhaled Carbon Monoxide Measurement versus Conventional Counselling on Smokers' Intention to Quit and Cigarette Consumption
}

(Kesan Bantuan Kaunseling Berhenti Merokok dengan Ukuran Hembusan Karbon Monoksida berbanding Kaunseling Konvensional terhadap Niat Perokok untuk Berhenti dan Penggunaan Rokok)

NoOrsyarida Shadan, Hizlinda Tohid*, Chai-Eng Tan, Nuraida BAHARuddin, Noor Azimah MuHAMmad \& SHAMSUl AZHAR SHAH

\section{ABSTRACT}

Feedback on exhaled carbon monoxide (CO) levels may potentially improve smokers' motivation to quit. However, evidence to support its use is still lacking. This study aimed to examine how providing feedback on exhaled CO measurement affected smokers' intention to quit and cigarette consumption short term. This non-randomised controlled trial was conducted at a government health clinic. The control group $(n=132)$ received conventional counselling using the $5 \mathrm{~A}$ approach and pamphlets, whereas the intervention group $(n=132)$ received similar counselling along with feedback on exhaled CO measurements. Subjects'intention to quit in the next month and current cigarette consumption were assessed at baseline and again four weeks post-counselling. At the baseline, there were significant differences between the groups in terms of gender $(p=0.002)$, ethnicity $(p=0.004)$, marital status $(p=0.002)$, age of smoking initiation $(p<0.001)$, nicotine dependence $(p=0.001)$ and quit intention $(p<0.001)$. Compared to the control group, those who received intervention started smoking at a younger age and had greater nicotine dependence, but they had stronger quit intentions. One month post-counselling, there were no differences in quit intention $(p=0.389)$ and cigarette consumption ( $p=0.902)$ between the groups. However, within-group analysis shows both a significant improvement in quit intention ( $p<0.001$ for both groups) and a reduction in cigarette consumption ( $p<0.001$ for both groups) after the counselling. None of the participants quit smoking at follow-up. In conclusion, both conventional smoking cessation counselling and counselling with feedback on exhaled carbon monoxide levels were similarly effective in improving smokers' quit intention and reducing cigarette consumption. However, this enhanced motivation was inadequate to make them quit.

Keywords: Carbon monoxide; counselling; intention; smoking cessation; tobacco use

ABSTRAK

Maklum balas mengenai paras karbon monoksida (co) yang dihembus perokok berpotensi untuk mempengaruhi motivasi perokok untuk berhenti merokok tetapi keberkesanan kaedah ini masih kekurangan bukti. Kajian ini bertujuan untuk meneliti bagaimana maklum balas terhadap ukuran hembusan CO dapat menyebabkan perokok berniat untuk berhenti merokok dan mengurangkan pengambilan rokok dalam jangka pendek. Kajian terkawal yang tidak rawak telah dijalankan di klinik kesihatan kerajaan. Kumpulan terkawal $(n=132)$ menerima kaunseling konvensional menggunakan kaedah 5 A dan risalah manakala kumpulan intervensi $(n=132)$ menerima kaunseling yang sama dan maklum balas terhadap ukuran hembusan CO. Subjek yang berniat untuk berhenti merokok pada bulan berikutnya dan pengambilan rokok yang dihisap telah dinilai pada permulaan kajian dan dinilai sekali lagi empat minggu selepas kaunseling. Pada permulaan kajian, terdapat perbezaan yang ketara antara kumpulan daripada segi jantina ( $p=0.002)$, bangsa $(p=0.004)$, status perkahwinan $(p=0.002)$, umur mula merokok $(p<0.001)$, kebergantungan kepada nikotin $(p=0.001)$ dan niat untuk berhenti merokok $(p<0.001)$. Berbanding dengan kumpulan terkawal, mereka yang menerima intervensi mula merokok pada usia yang muda dan mempunyai kebergantungan nikotin yang tinggi, tetapi mereka mempunyai niat untuk berhenti merokok yang lebih tinggi. Sebulan selepas sesi kaunseling, tiada perbezaan signifikan dari segi niat perokok untuk berhenti merokok $(p=0.389)$ dan bilangan rokokyang dihisap $(p=0.902)$ antara kumpulan intervensi dengan kumpulan kawalan. Namun, analisis dalam kumpulan menunjukkan bahawa kedua-dua kumpulan ini mempunyai peningkatan yang ketara dari segi niat untuk berhenti merokok ( $<<0.001$ untuk kedua-dua kumpulan) dan pengurangan pengambilan rokok ( $<<0.001$ untuk kedua-dua kumpulan) selepas sesi kaunseling. Pada penilaian susulan selepas sebulan, tiada perokok yang telah berjaya berhenti merokok. Kesimpulannya, kedua-dua kaedah kaunseling biasa dan pemberian maklum balas berkenaan paras karbon monoksida dalam nafas yang dihembus adalah sama-sama berkesan untuk meningkatkan niat berhenti merokok dan mengurangkan bilangan rokok yang dihisap. Namun, peningkatan niat berhenti merokok ini masih belum berjaya untuk menggerakkan perokok untuk berhenti merokok.

Kata kunci: Berhenti merokok; karbon monoksida; kaunseling; keinginan; penggunaan tembakau 


\section{INTRODUCTION}

As a result of powerful tobacco control efforts worldwide, the global prevalence of smoking has declined steadily over the past two decades (WHO 2018). In Malaysia, the prevalence of smoking decreased from $24.8 \%$ in 1996 to $22.8 \%$ in 2015 (IPH 2015, 1997; Lim et al. 2018). The improvement followed the implementation of a variety of strategies including the provision of smoking cessation services in both government and private settings (IPH 2015).

Primary healthcare providers have a responsibility to offer smoking cessation when they meet smokers during any consultation. This opportunistic smoking cessation advice is effective in increasing the quit rate by 1 to $3 \%$, even when it is brief (Stead et al. 2013). However, intensive counselling shows additional advantages over brief advice and additional tools are often used to assess smoking-related risks (e.g. exhaled carbon monoxide (CO) levels) or smoking-related harm (e.g. spirometry) (Bize et al. 2012; Stead et al. 2013). These assessments allow provision of personalised feedback on the physical effects of smoking, which can trigger feelings of threat and increase smokers' motivation to quit (McClure et al. 2009; Sanders et al. 1989; Shahab et al. 2011). This enhanced cognitive reaction may subsequently lead to lower cigarette consumption and eventually smoking abstinence (Sanders et al. 1989).

$\mathrm{CO}$ is a poisonous gas produced when a tobacco cigarette is lit and inhaled by smokers. In clinical practice, a CO breath analyser is used to measure CO in smokers' lungs to validate abstinence (Vasthare et al. 2018). Smoking dependence can also be evaluated based on exhaled CO levels, as $\mathrm{CO}$ accumulates in the lungs with heavy smoking. Previous studies have demonstrated that providing feedback about exhaled CO measurements can be effective in enhancing smokers' motivation to quit both immediately after counselling (McClure et al. 2009; Shahab et al. 2011) and four weeks post-counselling (Choi et al. 2013). However, the intervention did not significantly cause smokers to completely abstain from smoking (Choi et al. 2013; Sanders et al. 1989). This positive effect appears to be temporary and could not be translated into behavioural change (Shahab et al. 2011). Thus, its use as a motivational tool has not been strongly supported by two Cochrane systemic reviews (Bize et al. 2012; Stead et al. 2013).

In Malaysia, counselling using these adjunctive aids is appealing as many smokers are not ready to quit and added counselling may enhance their motivation to quit (IPH 2012; Li et al. 2010). However, few studies have assessed the effectiveness of this aided counselling on Malaysian smokers, therefore, its usefulness remains uncertain. In view of this gap in knowledge, this study aimed to assess the effect of exhaled CO measurement and feedback about it on smokers' intention to quit one month after counselling. In this study, the intervention group received aided counselling (brief advice, pamphlets, and a measurement of exhaled $\mathrm{CO}$ with feedback) whereas the control group received conventional counselling (brief smoking cessation advice and pamphlets only). The secondary outcome of this study was change in smoking behaviour one month post-counselling in terms of current cigarette consumption and seven-day smoking abstinence. It is hoped that this study provides evidence on the usefulness of exhaled $\mathrm{CO}$ measurements and related feedback in promoting smoking cessation among smokers in a primary care setting.

\section{MATERIALS AND METHODS}

This was a non-randomised controlled trial, conducted at a major urban government health clinic in Penang, Malaysia. As the study was done at one primary care clinic, randomisation and blinding could not be executed without a risk of treatment contamination. Thus, recruitment of participants for the control and intervention groups was conducted at two different times, to minimise treatment contamination.

In this study, adult current smokers (defined as those who have smoked at least 100 cigarettes in their lifetime) were invited to participate in the study. They were subsequently screened for their stages of smoking cessation, defined according to the Trans-Theoretical Model of Change (TTM) (DiClemente et al. 1991). In this study, the pre-contemplation stage was defined as when current smokers had no intention to quit in the next six months. Current smokers who seriously considered quitting smoking in the next six months were categorised as in the contemplation stage, while those who had decided to quit smoking in the next 30 days were considered in the preparation stage. Only smokers in the pre-contemplation, contemplation or preparation stage were invited to participate in this study. Those who had quit smoking (and were in the action or maintenance stage) were excluded from the study. Other exclusion criteria included being illiterate in either Malay or English language, concurrent addiction to other substances, pregnancy, significant cognitive impairment and any acute condition which required immediate medical attention.

The sample size was calculated to obtain a power of $80 \%$ to detect a difference in intention to quit of 0.55 with standard deviation of 1.45 (Shahab et al. 2011) and $\alpha$ of 0.05 . The calculated sample size was 132 subjects each for the intervention group and the control group, after accounting for a possibility of a $20 \%$ dropout rate.

Recruitment of subjects was conducted twice a week during morning clinic sessions between 17th November 2014 and 24th February 2015. The main researcher recruited control group participants between 17th November 2014 and 14th January 2015 and intervention group participants between 15th January 2015 and 27th February 2015. Potential subjects were approached after they had registered at the clinic. They 
were subsequently screened for their eligibility using a brief self-administered questionnaire. The questionnaire assessed the number of cigarettes smoked in the potential subject's lifetime to identify ever-smokers and their stage of smoking based on the TTM. Those who met the study criteria were briefed about the study and included as study participants after providing written consent.

Participants in both groups received 15-min conventional counselling sessions using the standardised 5A approach ('ask, assess, advise, assist and arrange follow-up'), which was developed based on previous literature (Aveyard et al. 2011; Pignone et al. 2011; Tobacco 2008; Zwar et al. 2011), as well as opinions from a family medicine specialist who has experience in smoking cessation. The content of each counselling session was tailored according to the participant's intention to quit in the next one month. All participants also received pamphlets about smoking, the dangers of smoking and tips on how to stop smoking, published by the Ministry of Health Malaysia. In addition to this conventional counselling, the participants in the intervention group underwent exhaled $\mathrm{CO}$ measurement using a piCO $^{+}$ Smokerlyzer $^{\circledR}$ (Bedfront Scientific Ltd., Rochester, UK). Based on their readings, intervention group participants were categorised as either light smokers (7-10 ppm) or smokers with high carbon monoxide levels ( $>10 \mathrm{ppm})$. Those with CO levels of 16-25 ppm were considered frequent smokers, while smokers with CO levels of $>25$ ppm were regarded as addicted smokers. The participants were informed of the results and also provided with an explanation of the adverse impacts of carbon monoxide on health. The aided counselling took an additional 15 min to deliver, therefore, the total counselling time for the intervention group was $30 \mathrm{~min}$.

The primary outcome measured in this study was participants' intention to quit smoking. This was measured using a single-item 7-point Likert scale response to the question: "How likely are you to stop smoking in the next 1 month?", where 1 indicated "Not at all likely" and 7 indicated "Extremely likely". The secondary outcomes were self-reported current daily cigarette consumption and seven-day smoking abstinence. Both primary and secondary outcomes were measured at baseline using a self-administered questionnaire and one month after counselling via telephone. Other smoking-related information assessed at the baseline included level of nicotine dependence (based on the Fagerstrom test for nicotine dependence), history of previous quit attempts and age of smoking initiation.

Data was entered into and analysed using IBM ${ }^{\circledR}$ SPSS version 25. A Wilcoxon signed ranks test was used to compare the level of intention to quit smoking and cigarette consumption within each group at baseline and one month post-counselling (within-group analysis). A chi-square test was used to compare the proportions of participants with change between both groups in terms of: quit intention ('no or negative change' versus 'positive change') and cigarette consumption ('no change or increase in consumption' versus 'reduction in consumption'). The level of significance was set at $<0.05$.

Ethical approval was obtained from both the Universiti Kebangsaan Malaysia Medical Research and Ethics Committee (FF-2014-227) and the Ministry of Health Medical Research and Ethics Committee (NMRR ID: 14-1048-19512). All smokers who were screened for eligibility to participate in this study received some form of smoking cessation advice and only those who provided written consent received the structured counselling. Smokers who were interested in stopping smoking were referred to the Quit Smoking Clinic for further advice and support.

\section{RESULTS}

A total of 290 smokers were screened for their eligibility to participate in this study, but only 264 (132 for each group) met the inclusion and exclusion criteria and were recruited into the study (Figure 1). After one month, all were contacted by phone for post-counselling assessment. Only $84.8 \%(\mathrm{n}=112)$ from the intervention group and $80 \%(n=110)$ from the control group answered the calls. The uncontactable participants were assumed to have the same intention to quit smoking and to have continued the same cigarette consumption as before counselling (intention-to-treat).

\section{SOCIODEMOGRAPHIC AND SMOKING-RELATED}

CHARACTERISTICS OF THE PARTICIPANTS AT THE BASELINE

The median (IQR) ages of the participants in the intervention group and control groups were 40.5 (18.8) years and 40.0 (19.0) years, respectively, which were not statistically different $(\mathrm{p}=0.381)$ (Table 1$)$. At the baseline, there were significant differences between the control and intervention groups in terms of gender $(p=0.002)$, ethnicity $(p=0.004)$, marital status $(p=0.002)$, age of smoking initiation $(\mathrm{p}<0.001)$, nicotine dependence $(p=0.001)$ and intention to quit $(p<0.001)$. Compared to the control group, those in the intervention group started smoking at a younger age (Median (IQR) age of smoking initiation: 20.0 (3.0) years (intervention), 23.0 (6.0) years (control); $\mathrm{p}<0.001)$. The intervention group also had a higher level of nicotine dependence (Median (IQR) Fagerstrom score: 4.0 (3.0) (intervention), 3.0 (4.0) (control); $\mathrm{p}=0.001)$. However, the intervention group generally had a stronger quit intention than the control group $(p<0.001)$. Compared to the smokers in the control group, the intervention group had significantly more participants who had 'Intention to quit' (Intervention group: $64.4 \%$ versus Control group: $38.6 \%$ ), but fewer with 'No intention to quit' (Intervention group: 6.8\% versus Control group: 16.7\%) and 'Neither likely/unlikely to quit' (Intervention group: $28.8 \%$ versus Control group: $44.7 \%$ ). 


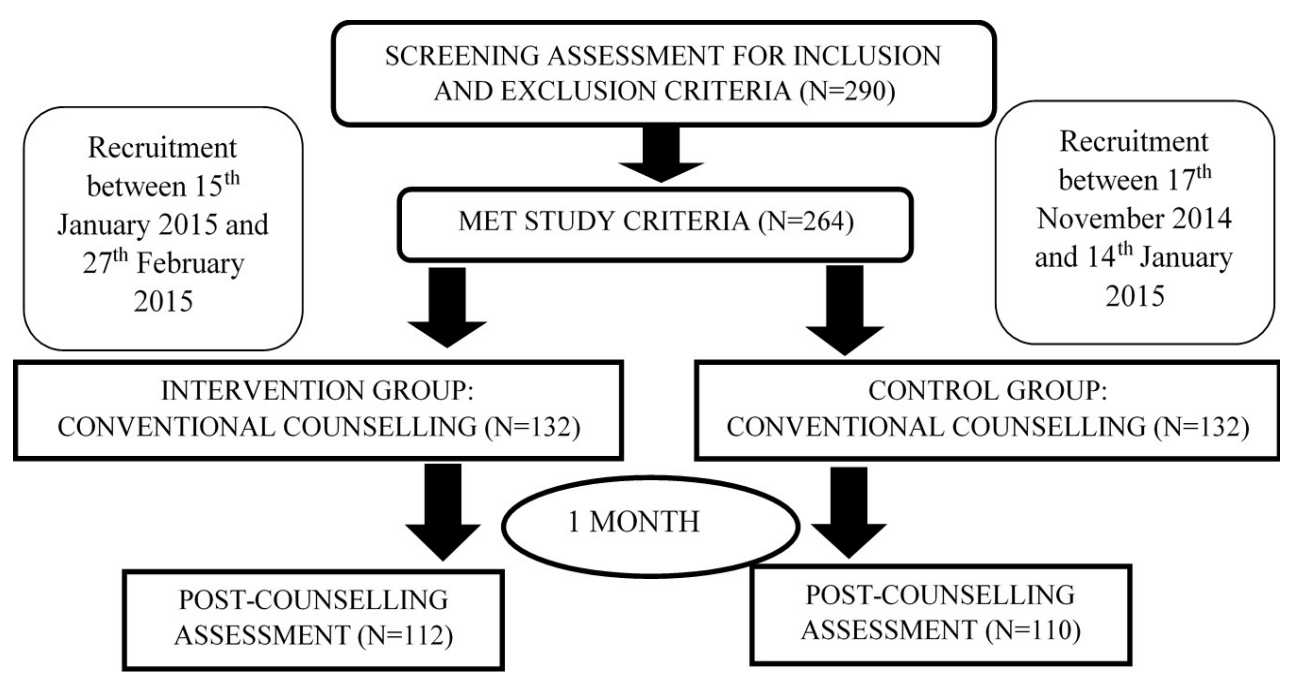

FIGURE 1. Consort flow diagram of the study

TABLE 1. Sociodemographic and smoking-related characteristics of the participants at the baseline

\begin{tabular}{|c|c|c|c|}
\hline Baseline characteristics & $\begin{array}{l}\text { Control group } \\
(\mathrm{N}=132)\end{array}$ & $\begin{array}{l}\text { Intervention group } \\
\qquad(\mathrm{N}=132)\end{array}$ & P-value \\
\hline Age (year) [Median (IQR)] & $40.0(19.0)$ & $40.5(18.75)$ & $0.381^{\mathrm{a}}$ \\
\hline \multicolumn{4}{|l|}{ Gender $[\mathrm{n}(\%)]$} \\
\hline Male & $102(77.3)$ & $120(90.9)$ & \multirow{2}{*}{$0.002^{\mathrm{b}}$} \\
\hline Female & $30(22.7)$ & $12(9.1)$ & \\
\hline \multicolumn{4}{|l|}{ Ethnicity [n (\%)] } \\
\hline Malay & $42(31.8)$ & $60(45.4)$ & \multirow{4}{*}{$0.004^{\mathrm{b}}$} \\
\hline Chinese & $67(50.7)$ & $41(31.1)$ & \\
\hline Indian & $15(11.4)$ & $26(19.7)$ & \\
\hline Others & $8(6.1)$ & $5(3.8)$ & \\
\hline \multicolumn{4}{|l|}{ Education level [n (\%)] } \\
\hline Primary & $9(6.8)$ & $4(3.0)$ & \multirow{3}{*}{$0.196^{\mathrm{b}}$} \\
\hline Secondary & $37(28.0)$ & $47(35.6)$ & \\
\hline Tertiary & $86(65.2)$ & $81(61.4)$ & \\
\hline \multicolumn{4}{|l|}{ Marital status $[\mathrm{n}(\%)]$} \\
\hline Married & $60(45.4)$ & $85(64.4)$ & \multirow{2}{*}{$0.002^{\mathrm{b}}$} \\
\hline Non-married & $72(54.6)$ & $47(35.6)$ & \\
\hline Age of smoking initiation (years) [Median (IQR)] & $23.0(6.0)$ & $20.0(3.0)$ & $<0.001^{\mathrm{a}}$ \\
\hline Past quit attempts [Median (IQR)] & $3.0(3.0)$ & $3.0(3.0)$ & $0.221^{\mathrm{a}}$ \\
\hline Cigarette consumption per day [Median (IQR)] & $12.0(5.0)$ & $15.0(10.0)$ & $0.254^{\mathrm{a}}$ \\
\hline Fagerstrom score [Median (IQR)] & $3.0(4.0)$ & $4.0(3.0)$ & $0.001^{\mathrm{a}}$ \\
\hline \multicolumn{4}{|l|}{ Nicotine dependence based on Fagestrom score } \\
\hline Very low $(0-2)[\mathrm{n}(\%)]$ & $53(40.1)$ & $24(18.2)$ & \multirow{3}{*}{$<0.001^{\mathrm{t}}$} \\
\hline Low $(3-4)[\mathrm{n}(\%)]$ & $36(27.3)$ & $50(37.9)$ & \\
\hline Moderate to high $(\geq 5)[\mathrm{n}(\%)]$ & $43(32.6)$ & $58(43.9)$ & \\
\hline \multicolumn{4}{|l|}{ Intention to quit within 1 month $[\mathrm{n}(\%)]$} \\
\hline No & $22(16.7)$ & $9(6.8)$ & \multirow{3}{*}{$<0.001^{\text {b }}$} \\
\hline Neither & $59(44.7)$ & $38(28.8)$ & \\
\hline Yes & $51(38.6)$ & $85(64.4)$ & \\
\hline
\end{tabular}

${ }^{a}$ Mann-Whitney test

${ }^{\mathrm{b}} \mathrm{Chi}$-square test 
Both groups were similar at the baseline in terms of educational level $(p=0.196)$, number of past quit attempts $(p=0.221)$ and cigarette consumption per day $(p=0.254)$. The participants in the control group smoked about 12 (IQR 5.0) cigarettes per day, whereas the participants in the intervention group smoked about 15 (IQR 10.0) cigarettes per day.

\section{INTENTION TO QUIT IN THE NEXT ONE MONTH BEFORE AND AFTER RECEIVING COUNSELLING}

Figure 2 shows a detailed illustration of the participants' intention to quit within the next one month at the baseline. More participants in the control group admitted that they were unlikely $(16.7 \%)$ or neither likely/unlikely
$(57.6 \%)$ to quit compared to those in the intervention group. Most of the participants in the intervention group $(64.4 \%)$ said that they were likely to quit in the next month compared to the participants in the control group (38.6\%). However, after receiving counselling, more participants in the control group (67.4\%) said that they were likely to quit in the next month (Figure 3) compared to the proportion at the baseline $(38.6 \%)$ (Figure 2$)$. The proportion of participants in the intervention group who wanted to quit also increased from $64.4 \%$ (Figure 2) to $87.9 \%$ (Figure 3 ). Some participants in both groups even said that they were extremely likely to quit $(3.0 \%$ of the control group and $3.8 \%$ of the intervention group).

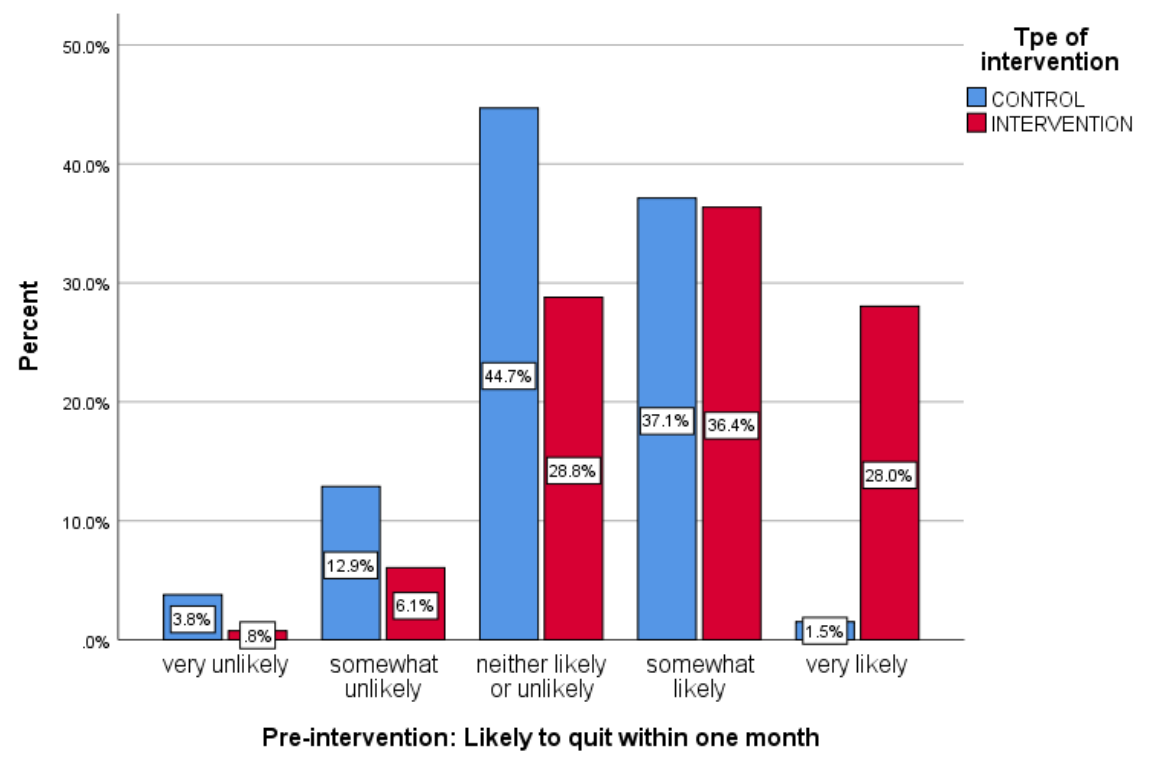

FIGURE 2. Intention to quit at the baseline among participants in the intervention and control groups

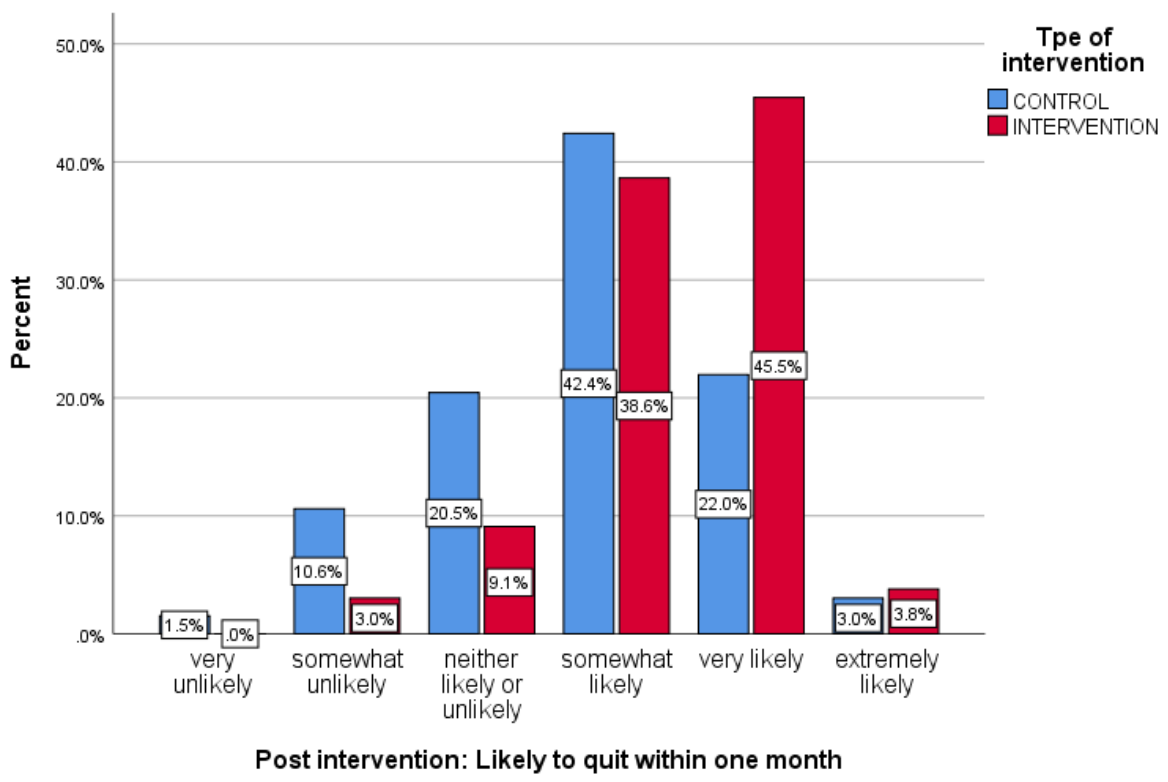

FIGURE 3. Intention to quit at 1-month follow-up among participants in the intervention and control groups 
WITHIN-GROUP ANALYSIS: EFFECTS OF BOTH COUNSELLING TYPES ON THE PARTICIPANTS' INTENTION TO QUIT SMOKING, DAILY CIGARETTE CONSUMPTION AND SMOKING CESSATION

There was a significant difference in the participants' intention to quit after receiving either conventional counselling (control group: $\mathrm{p}<0.001$ ) or aided counselling (intervention group: $\mathrm{p}<0.001$ ) (Table 2). There was also a significant reduction in daily cigarette consumption after participants received either conventional counselling $(p<0.001)$ or aided counselling $(p<0.001)$. In the control group, median (IQR) daily cigarette consumption levels before and after counselling were 12.0 (5.0) and 10.0 (7.0) cigarettes per day, respectively. In the intervention group, median (IQR) daily cigarette consumption levels before and after counselling were $15.0(10.0)$ and 10.0 (5.0), respectively. None of the participants from either group reported seven-day smoking abstinence at the follow-up.

\section{BETWEEN-GROUPS ANALYSIS: EFFECTS OF AIDED COUNSELLING ON THE PARTICIPANTS' INTENTION TO QUIT SMOKING AND DAILY CIGARETTE CONSUMPTION COMPARED TO CONVENTIONAL COUNSELLING}

There was no significant difference between the intervention and control groups in terms of changes in participants' quit intention $(\mathrm{p}=0.389)$ or daily cigarette consumption $(\mathrm{p}=0.902)$ after they received the smoking cessation counselling (Table 3 ).

TABLE 2. Within-group analysis: Effects of both counselling on participants' intention to quit smoking and daily cigarette consumption

\begin{tabular}{|c|c|c|c|c|c|c|}
\hline \multirow{2}{*}{$\begin{array}{l}\text { Within-group } \\
\text { analysis }\end{array}$} & \multicolumn{2}{|c|}{$\begin{array}{l}\text { Control group } \\
(\mathrm{N}=132)\end{array}$} & \multirow{2}{*}{ p-value } & \multicolumn{2}{|c|}{$\begin{array}{l}\text { Intervention group } \\
\qquad(\mathrm{N}=132)\end{array}$} & \multirow{2}{*}{ P-value } \\
\hline & Pre counselling & Post counselling & & Pre counselling & Post counselling & \\
\hline $\begin{array}{l}\text { Intention to } \\
\text { quit smoking } \\
\text { [Median (IQR)] }\end{array}$ & $4.0(1.0)$ & $5.0(2.0)$ & $<0.001^{\mathrm{a}}$ & $5.0(2.0)$ & $5.0(1.0)$ & $<0.001^{\mathrm{a}}$ \\
\hline $\begin{array}{l}\text { Daily cigarette } \\
\text { consumption } \\
\text { [Median (IQR)] }\end{array}$ & $12.0(5.0)$ & $10.0(7.0)$ & $<0.001^{\mathrm{a}}$ & $15.0(10.0)$ & $10.0(5.0)$ & $<0.001^{\mathrm{a}}$ \\
\hline
\end{tabular}

${ }^{a}$ Wilcoxon Signed Ranks Test using related samples; Significance level $<0.05$

\#7-Likert scale response of likeliness to quit smoking within 1 month: Extremely unlikely (1), Very unlikely (2), Somewhat unlikely (3), Neither likely or unlikely (4), Somewhat likely (5), Very likely (6) and Extremely likely (7)

TABLE 3. Between-groups analysis: Effects of aided counselling on intention to quit smoking and daily cigarette consumption compared to conventional counselling

\begin{tabular}{lccc}
\hline \multicolumn{1}{c}{ Between-groups analysis } & $\begin{array}{c}\text { Control group } \\
(\mathrm{N}=132)\end{array}$ & $\begin{array}{c}\text { Intervention group } \\
(\mathrm{N}=132)\end{array}$ & P-value \\
\hline $\begin{array}{l}\text { Change in quit intention after intervention }[\mathrm{n}(\%)] \\
\text { No or negative change in quit intention }\end{array}$ & $60(45.5)$ & $67(50.8)$ & $0.389^{\mathrm{a}}$ \\
$\quad$ Positive change in quit intention & $72(54.5)$ & $65(49.2)$ \\
Change in daily cigarette consumption after intervention [n (\%)] & & $71(53.8)$ & $72(54.5)$ \\
$\quad$ No change or increase in cigarette consumption & $61(46.2)$ & $60(45.5)$ & $0.902^{\mathrm{a}}$ \\
\hline
\end{tabular}

${ }^{\mathrm{a} C h i-s q u a r e ~ t e s t ; ~ S i g n i f i c a n c e ~ l e v e l ~}<0.05$ 


\section{DISCUSSION}

This study was an intervention trial conducted at a government primary care clinic that used a nonrandomised controlled trial design. Recruitment of participants into the control and intervention groups was done at two different times to minimise contamination bias and logistical problems. Because of the clinic setting, it was difficult to provide both types of counselling on the same day without blinding the participants of the other intervention that they did not receive. Due to this, some of the characteristics of the participants at the baseline were varied significantly between the two groups. These characteristics include gender, ethnicity, marital status, age of smoking initiation, nicotine dependence, and intention to quit within the next month. Compared to the control group, the participants in the intervention group started smoking at a younger age. They had greater nicotine dependence at the baseline but had greater intention to quit in the next month. Most of them were in the preparation stage. Recruitment of these participants just after the New Year (in January and February) could also explain why they were more motivated to quit than the participants in the control group. It is common for people to make resolutions to improve their health behaviour at that time of the year.

This significantly variation in characteristics at the baseline may affect the findings of this study. In this study, the short-term effects of aided counselling using exhaled $\mathrm{CO}$ measurements and related feedback on the participants' intention to quit, daily cigarette consumption and smoking abstinence were similar to those of conventional counselling. Thus, the effectiveness of this intervention in increasing smokers' motivation to quit could not be demonstrated. It appears that this intervention did not offer any advantage over the usual quit smoking counselling. This is in line with the findings of a systematic review by Stead et al. (2013) that showed small or non-existent benefits of intensive counselling, especially when it involves unselected healthy smokers, which describes many patients in the primary care settings. An older study conducted in the UK by Sanders et al. (1989) and a recent study conducted in Korea by Choi et al. (2013) also demonstrated insignificant differences in smoking abstinence one month post-intervention when compared with the control. At one month follow-up, similar smoking abstinence rates were noted between the control group and an intervention group that used personal CO monitoring using a smartphone application (Krishnan et al. 2018). However, in the study by Choi et al. (2013), significantly more smokers in the intervention group $(22.7 \%)$ had increased motivation to quit at one month follow-up compared to those in the control group (5.9\%). This additional benefit of the aided counselling was not observed in the current study, even though the intervention group participants were initially more motivated to quit than the smokers in the control group, suggesting that they were more likely to quit smoking.
The insignificant difference in the outcomes between the groups may be due to the greater nicotine dependence of the smokers who received the aided counselling. They were found to be more dependent on nicotine than those in the control group. Even though they appeared to be more motivated, this nicotine dependence may have made attempting to quit in the month after the aided counselling a disheartening struggle, especially if they have low self-efficacy (Shahab et al. 2011). It may have impaired the beneficial effects of the aided counselling. Therefore, a proper randomised controlled trial might still be able to prove its effectiveness over the conventional counselling.

Nevertheless, this study demonstrated the effectiveness of both conventional and aided counselling in improving smokers' intention to quit and reducing cigarette consumption one month post-intervention. Increased quit intention was also observed in both the control and intervention groups in Shahab et al. (2011), but it was measured immediately after the intervention. Both approaches raised the smokers' perception of their susceptibility to airway disease and their belief that quitting could lower their tendency of getting airway disease (Shahab et al. 2011). However, their quit intention returned to baseline levels by the six-month followup, which suggests that the effects of both approaches are temporary (Shahab et al. 2011). Other studies that conducted follow-up after one month did not perform within-group analysis (Choi et al. 2013; Sanders et al. 1989), except for Krishnan et al. (2018). In the latter study, a positive change in the 'Reasons for quitting scale' score was demonstrated in the intervention group, but the control had a negative change in the score (DiClemente et al. 1991). Due to a lack of previous studies, we cannot make a direct comparison of our findings with others, limiting our interpretation. However, our study did highlight the usefulness of both conventional and aided counselling in promoting smoking cessation in a primary care setting. As this study did not demonstrate superiority of the aided counselling, conventional counselling may be adequate and does not incur additional costs. However, the enhanced motivation produced by both conventional and aided counselling may not be enough to motivate participants to quit, as none had abstained from smoking by the follow-up. The likelihood of smokers to quit is higher if they have high self-efficacy (Shahab et al. 2011), therefore, healthcare providers should use this opportunity to provide effective interventions to the motivated smokers within four weeks of the initial counselling by providing pharmacotherapy and improving their self-efficacy. These interventions could increase the likelihood that participants are able to quit successfully (Cahill et al. 2013).

This study was one of the first studies in Malaysia to examine the effectiveness of exhaled $\mathrm{CO}$ measurements and related feedback in changing smokers' intention to quit and reducing their cigarette consumption. Although 
the superiority of the aided counselling using $\mathrm{CO}$ measurements over conventional counselling was not demonstrated, the positive effects of both counselling types were promising. This study also used 'intention-totreat analysis' to maintain the prognostic balance between the intervention and control groups due to missing responses. However, the participants in this study were not randomly assigned to the two groups, which reduces the benefits of using this type of analysis.

Due to non-randomisation, the participants in the control and intervention groups were also significantly different in certain ways. The different times of year at which participants were recruited into each group may have worsened the differences between the groups. Thus, the unequal characteristics of the two groups at the baseline may complicate interpretation of the findings. The measured benefits of the conventional and the aided counselling were also limited to short-term effects, measured one month after the intervention. Future studies should also examine long-term effects, monitored up to a year post intervention. Another limitation of the study was related to the self-reported outcomes that were obtained over the phone. This method of data collection can result in response bias.

\section{CONCLUSION}

The effectiveness of exhaled CO measurement and related feedback as an aid in smoking cessation counselling to further increase smokers' motivation to quit could not be demonstrated by the current study. It appears that this intervention did not offer any advantage over the usual quit smoking counselling, which could be partly due to the non-randomised study design. Interestingly, this study highlights the effectiveness of both aided and conventional counselling in enhancing smokers' intention to quit and reducing cigarette consumption four weeks after receiving the intervention. These findings suggest the potential usefulness of both counselling approaches in a primary care setting to promoting smoking cessation and improving smokers' motivation to quit. However, this motivation may still not be enough to make them quit, since none of the participants had stopped smoking at follow-up. Therefore, a more effective intervention, such as combined pharmacological and psychological therapy, should be provided after initial counselling to increase the likelihood that participants quit.

\section{ACKNOWLEDGEMENTS}

The authors would like to thank the Director General of Health Malaysia for his permission to publish this paper. Special thanks to the Family Medicine Specialist of the health clinic and all clinic staff who had given their support and assistance. This study was funded by the Universiti Kebangsaan Malaysia (FF-2014-227).

\section{REFERENCES}

Aveyard, P., Begh, R., Parsons, A. \& West, R. 2011. Brief opportunistic smoking cessation interventions: A systematic review and meta-analysis to compare advice to quit and offer of assistance. Addiction 107: 1066-1073.

Bize, R., Burnand, B., Mueller, Y., Rège-Walther, M., Camain, J.Y. \& Cornuz, J. 2012. Biomedical risk assessment as an aid for smoking cessation. Cochrane Database of Systematic Reviews 12: CD004705.

Cahill, K., Stevens, S., Perera, R. \& Lancaster, T. 2013. Pharmacological interventions for smoking cessation: An overview and network meta-analysis. Cochrane Database of Systematic Reviews 5: CD009329.

Choi, W.Y., Kim, C.H. \& Lee, O.G. 2013. Effects of brief smoking cessation education with expiratory carbon monoxide measurement on level of motivation to quit smoking. Korean Journal of Family Medicine 34(3): 190-198.

DiClemente, C.C., Prochaska, J.O., Fairhurst, S.K., Velicer, W.F., Velasquez, M.M. \& Rossi, J.S. 1991. The process of smoking cessation: An analysis of precontemplation, contemplation, and preparation stages of change. Journal of Consulting and Clinical Psychology 59: 295-304.

Institute for Public Health (IPH). 2015. National Health and Morbidity Survey 2015 - Report on Smoking Status among Malaysian Adults. http://www.moh.gov.my/moh/resources/ NHMS2015-VolumeV.pdf. Accessed on 23 June 2019.

Institute for Public Health (IPH). 2012. Report of the Global Adult Tobacco Survey (GATS) Malaysia, 2011. Kuala Lumpur: Ministry of Health Malaysia.

Institute of Public Health (IPH). 1997. National Health and Morbidity Survey (NHMS II). Volume 15: Smoking. Kuala Lumpur, Malaysia: Ministry of Health Malaysia.

Krishnan, K., Elf, J.L., Chon, S. \& Golub, J.E. 2018. COach2Quit: A pilot randomized controlled trial of a personal carbon monoxide monitor for smoking cessation. Nicotine \& Tobacco Research 21(11): 1573-1577.

Li, L., Borland, R., Yong, H.H., Fong, G.T., Bansal-Travers, M., Quah, A.C.K., Sirirassamee, B., Omar, M., Zanna, M.P. \& Fotuhi, O. 2010. Predictors of smoking cessation among smokers in Malaysia and Thailand: Findings from the International Tobacco Control Southeast Asia Survey. Nicotine \& Tobacco Research 12(1): S34-S44.

Lim, K.H., Teh, C.H., Pan, S., Ling, M.Y., Yusoff, M.F.M., Ghazali, S.M., Kee, C.C., Lim, K.K., Chong, K.H. \& Lim, H.L. 2018. Prevalence and factors associated with smoking among adults in Malaysia: Findings from the National Health and Morbidity Survey (NHMS) 2015. Tobacco Induced Diseases 16: 1-12.

McClure, J.B., Ludman, E., Grothaus, L., Pabiniak, C., Richards, J. \& Mohelnitzky, A. 2009. Immediate and short-term impact of a brief motivational smoking intervention using a biomedical risk assessment: The get PHIT trial. Nicotine \& Tobacco Research 11(4): 394-403.

Pignone, M. \& Salazar, R. 2011. Disease prevention \& health promotion. In Current Medical Diagnosis \& Treatment 2011. 15th ed, edited by Papadakis, M.A., McPhee, S.J. \& Rabow, M.W. New York: The McGraw-Hill Companies Inc. p. 9.

Sanders, D., Fowler, G., Mant, D., Fuller, A., Jones, L. \& Marzillier, J. 1989. Randomized controlled trial of anti- 
smoking advice by nurses in general practice. Journal of the Royal College of General Practitioners 39: 273-276.

Shahab, L., West, R. \& McNeill, A. 2011. A randomized, controlled trial of adding expired carbon monoxide feedback to brief stop smoking advice: Evaluation of cognitive and behavioral effects. Health Psychology 30(1): 49-57.

Stead, L.F., Buitrago, D., Preciado, N., Sanchez, G., HartmannBoyce, J. \& Lancaster, T. 2013. Physician advice for smoking cessation. Cochrane Database of Systematic Reviews 2013(5): Art. No.: CD000165. DOI: 10.1002/14651858. CD000165.pub4.

Tobacco, T.C.P.G.T. 2008. A clinical practice guideline for treating tobacco use and dependence: 2008 update: A US public health service report. American Journal of Preventive Medicine 35(2): 158-176.

Vasthare, R., Kumar, S. \& Arron, L.Y. 2018. Carbon monoxide breath analyzers and its role in tobacco cessation: A narrative review of literature. Journal of International of Oral Health 10: 71-76.

World Health Organization (WHO). 2018. WHO Global Report on Trends in Prevalence of Tobacco Smoking 2000-2025. 2nd ed. Geneva: World Health Organization. https://www. who.int/tobacco/publications/surveillance/trends-tobaccosmoking-second-edition/en/. Accessed on 23 June 2019.

Zwar, N., Richmond, R., Borland, R., Peters, M., Litt, J., Bell, J., Caldwell, B. \& Ferretter, I. 2011. Supporting Smoking Cessation: A Guide for Health Professionals. Melbourne: The Royal Australian College of General Practitioners.
Noorsyarida Shadan

Klinik Kesihatan Seberang Jaya

Ministry of Health Malaysia

Jalan Perpustakaan

13700 Butterworth, Pulau Pinang

Malaysia

Hizlinda Tohid*, Chai-Eng Tan, Nuraida Baharuddin \& Noor Azimah Muhammad

Department of Family Medicine

Faculty of Medicine

Universiti Kebangsaan Malaysia

Jalan Yaacob Latif, Bandar Tun Razak

56000 Cheras, Kuala Lumpur, Federal Territory

Malaysia

Shamsul Azhar Shah

Department of Public Health

Faculty of Medicine

Universiti Kebangsaan Malaysia

Jalan Yaacob Latif, Bandar Tun Razak

56000 Cheras, Kuala Lumpur, Federal Territory

Malaysia

*Corresponding author; email: hizlinda2202@gmail.com

Received: 26 November 2019

Accepted: 6 April 2020 